\title{
Strangulated obturator hernia
}

\author{
Rahul Gupta, ${ }^{1}$ Harjeet Singh, ${ }^{1}$ Mandeep Kang, ${ }^{2}$ Rajinder Singh ${ }^{1}$
}

${ }^{1}$ Department of General Surgery, Postgraduate Institute of Medical Education and Research, Chandigarh, India ${ }^{2}$ Department of Radiology, Postgraduate Institute of Medical Education and Research, Chandigarh, India

\section{Correspondence to}

Dr Rahul Gupta, rahul.g.85@gmail.com

Accepted 2 November 2014
CrossMark

To cite: Gupta R, Singh $\mathrm{H}$ Kang $\mathrm{M}$, et al. BMJ Case Rep Published online: [please include Day Month Year] doi:10.1136/bcr-2014207071

\section{DESCRIPTION}

A frail 60-year-old woman presented with a 5-day history of pain in the abdomen, constipation, vomiting and abdominal distension. There was no history of surgery or tuberculosis. On examination, the abdomen was distended and non-tender. The hernial sites were normal. On auscultation, hyperperistaltic bowel sounds were present. On X-ray of the abdomen there were multiple air fluid levels. Contrast-enhanced CT of the abdomen and pelvis showed right-sided obturator hernia (arrow) containing ischaemic small bowel loops with intestinal obstruction (figure 1). At emergency laparotomy, the terminal ileum was found to be entering the right obturator foramen with gross dilation of proximal bowel loops (figure 2). On reduction of the hernia, the herniated bowel loop was found to be gangrenous; it was resected and primary anastomosis was performed. The hernial sac was also identified in the obturator region on the contralateral side (figure 3).

Obturator hernia is a rare type of abdominal wall hernia accounting for $0.05-0.4 \%$ of all cases. ${ }^{1}$ It is seen most commonly in frail, elderly multiparous females. ${ }^{1}$ Most cases present with acute intestinal obstruction and are diagnosed intraoperatively. ${ }^{2}$ The classical 'Howship-Romberg' and 'Hannington-Kiff' signs of obturator hernia are uncommon and often

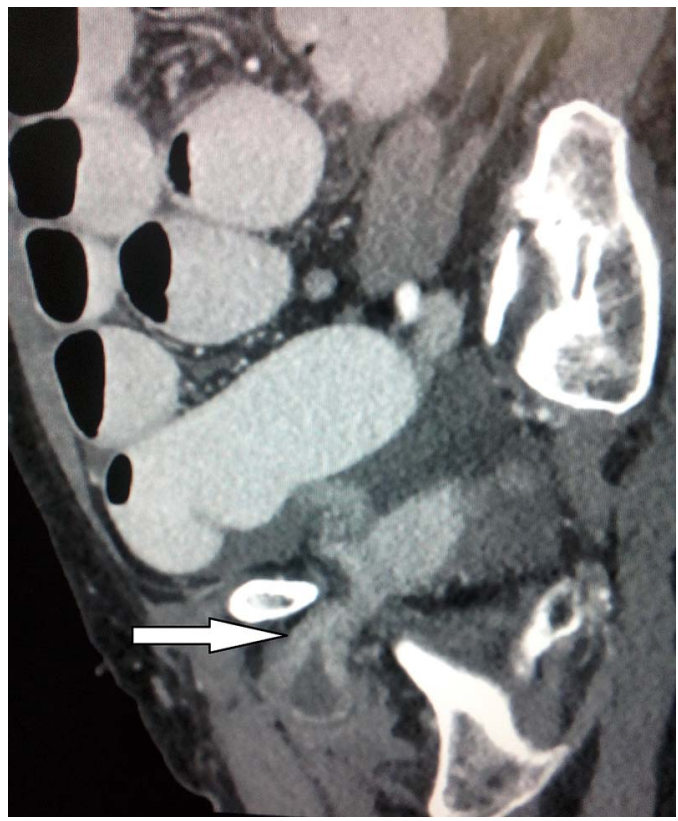

Figure 1 Contrast-enhanced CT of the abdomen and pelvis showing a right-sided obturator hernia (arrow) containing ischaemic small bowel loops with intestinal obstruction.

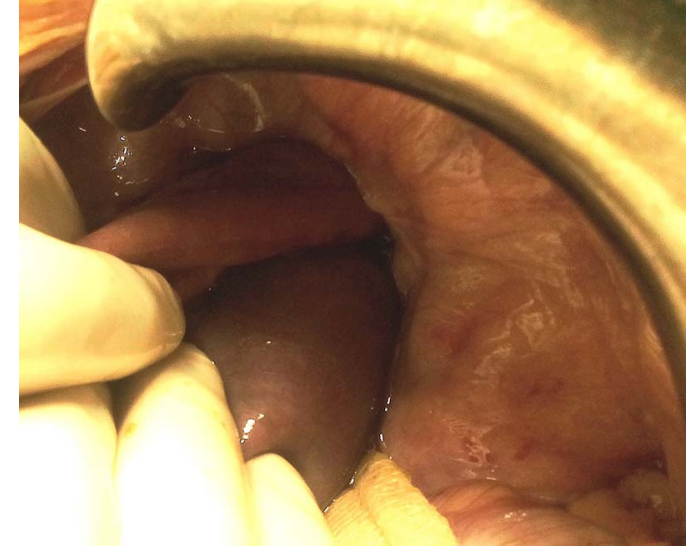

Figure 2 Intraoperative photograph showing terminal ileum enter the right obturator foramen with gross dilation of proximal bowel loops.

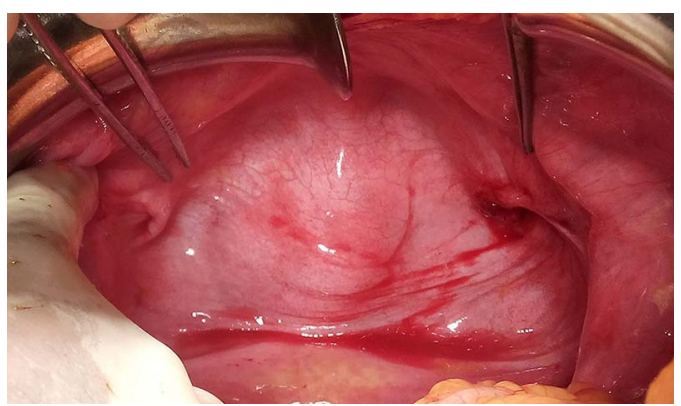

Figure 3 Intraoperative photograph showing presence of obturator hernial sac on both sides.

overlooked. ${ }^{1}$ CT of the abdomen has accuracy of $80 \%$ for making preoperative diagnosis. ${ }^{1}$ Treatment consists of reduction of hernial contents with primary closure of hernial defect with simple interrupted nonabsorbable sutures, which can be performed at laparotomy or by a laparoscopic approach based on the clinical condition of the patient. ${ }^{3}$

\section{Learning points}

- Obturator hernia should be suspected in frail elderly women presenting with acute intestinal obstruction.

- CT of the abdomen and pelvis is the imaging modality of choice for preoperative diagnosis of obturator hernia.

- Most of the cases can be managed by reduction of hernial contents with primary closure of hernial defect. 
Contributors RG was involved in writing, editing and approval of the manuscript. HS, MK and RS were involved in editing and approval of the manuscript.

Competing interests None.

Patient consent Obtained.

Provenance and peer review Not commissioned; externally peer reviewed.

\section{REFERENCES}

1 Chang SS, Shan YS, Lin YJ, et al. A review of obturator hernia and a proposed algorithm for its diagnosis and treatment. World I Surg 2005;29:450-4.

2 Gray SW, Skandalakis JE, Soria RE, et al. Strangulated obturator hernia. Surgery 1974;75:20-7.

3 Zeeshan S, Muhammad K, Chughtai J, et al. Strangulated obturator hernia—an unusual presentation of intestinal obstruction. J Coll Physicians Surg Pak 2009;19:582-3.

Copyright 2014 BMJ Publishing Group. All rights reserved. For permission to reuse any of this content visit http://group.bmj.com/group/rights-licensing/permissions.

BMJ Case Report Fellows may re-use this article for personal use and teaching without any further permission.

Become a Fellow of BMJ Case Reports today and you can:

- Submit as many cases as you like

- Enjoy fast sympathetic peer review and rapid publication of accepted articles

- Access all the published articles

- Re-use any of the published material for personal use and teaching without further permission

For information on Institutional Fellowships contact consortiasales@bmjgroup.com

Visit casereports.bmj.com for more articles like this and to become a Fellow 